\author{
Maria F. Barbés Fernández* , Érika Marinas García*, \\ Luis F. Verdeja González*, Fernando García Carcedo**, Ińigo Ruiz-Bustinza**, \\ Mirosław Karbowniczek***, Piotr Migas***
}

\title{
NEW BOF SLAGS CONTAINING SODIUM AND MANGANESE
}

\section{INTRODUCTION}

The world production of steel comes to about 1.350 million tons a year. Forty-five percent of that is made up of low carbon ferritic products $(\mathrm{C}<0.10 \%)$ while of the remaining amount, $25 \%, 25 \%, 10 \%$ and $20 \%$, respectively, are ferritic-perlitic steels $(\mathrm{C}=0.25 \%)$, perlitic $(\mathrm{C}=0.80 \%)$ and special products (stainless steel and high alloys). If we consider the variety of steel production methods, $65 \%$ is made using blast furnaces, $\mathrm{BF}$ - basic oxygen converter, BOF: BF-BOF, while the remaining $35 \%$ is made using an electric arc furnace.

Manganese has always been common in steel production, in both carbon steels and special products. However in recent years its role as an alloying element has been especially valuable due to the importance of high-strength and high tenacity steels. The presence of manganese in ferritic steel products simultaneously improves both resistance (yield strength, $\sigma_{y}$ ) and toughness (ITT ${ }^{\circ} \mathrm{C}$, Impact Transition Temperature), something that is not typical of alloying elements of substitutional and interstitial character.

Regarding the new generations of IF (Interstitial Free) steels, it can be said that the role of carbon and the interstitial elements (nitrogen, hydrogen and boron) has been relegated to the category of impurity. The presence of these elements notably reduces the tenacity of the product. For this reason, the content of carbon and nitrogen in commercial ferromanganese used in the production of ferritic steels needs to be evaluated. Recently, markets have opened up for refined low carbon ferromanganese and electrolytic steels that were unimaginable just a few years ago.

* Ph.D., M.Sc. Prof., Ph.D.: Universidad de Oviedo. Grupo de Investigación en Siderurgia, Metalurgia y Materiales. Escuela de Minas. Universidad de Oviedo. Spain (http://www.uniovi.es/sid-met-mat)

* Ph.D.: CENIM/CSIC, Primary Metallurgy Dpt., PROMESS Group. Spain

*** Ph.D., D.Sc.; Ph.D.: AGH University of Science and Technology, Faculty of Metals Engineering and Industrial Computer Science, Krakow, Poland; e-mail: mkarbow@agh.edu.pl 
Commercial ferromanganese $(\mathrm{Fe}-75 \% \mathrm{Mn})$ can reach carbon contents as low as $2.0 \%$. High-quality refined ferromanganese with a carbon content of less than $1.0 \%$ is in demand. However, it is necessary to use a new reducing agent (Fe-Mn-Si), which results in a final product (refined low carbon ferromanganese) containing silicon (from 0.30 to $0.80 \% \mathrm{Si}$ ), and the consequences of this must be faced. The industry has tried to avoid these compli-cations by encouraging the production of electrolytic manganese. The main drawback of using electrolytic manganese steel is its cost of US $\$ 3,000 /$ t. compared to US $\$ 1,500 / t$. of low-carbon ferromanganese: $\mathrm{Fe}-75 \% \mathrm{Mn}$ with less than 1.0\% C [1, 2].

\section{BYPRODUCTS OF THE BOF PROCESS}

In Figure 1 can be seen the general characteristics of the thermal refining process of iron in a BOF-LD converter with a gas mixture as follows: oxygen at a speed of dimensionless Mach 2.2 enters through lances in the upper part, while inert or lightly oxidizing gases $\left(\mathrm{CO}_{2}\right)$ are injected through nozzles in the bottom [3].

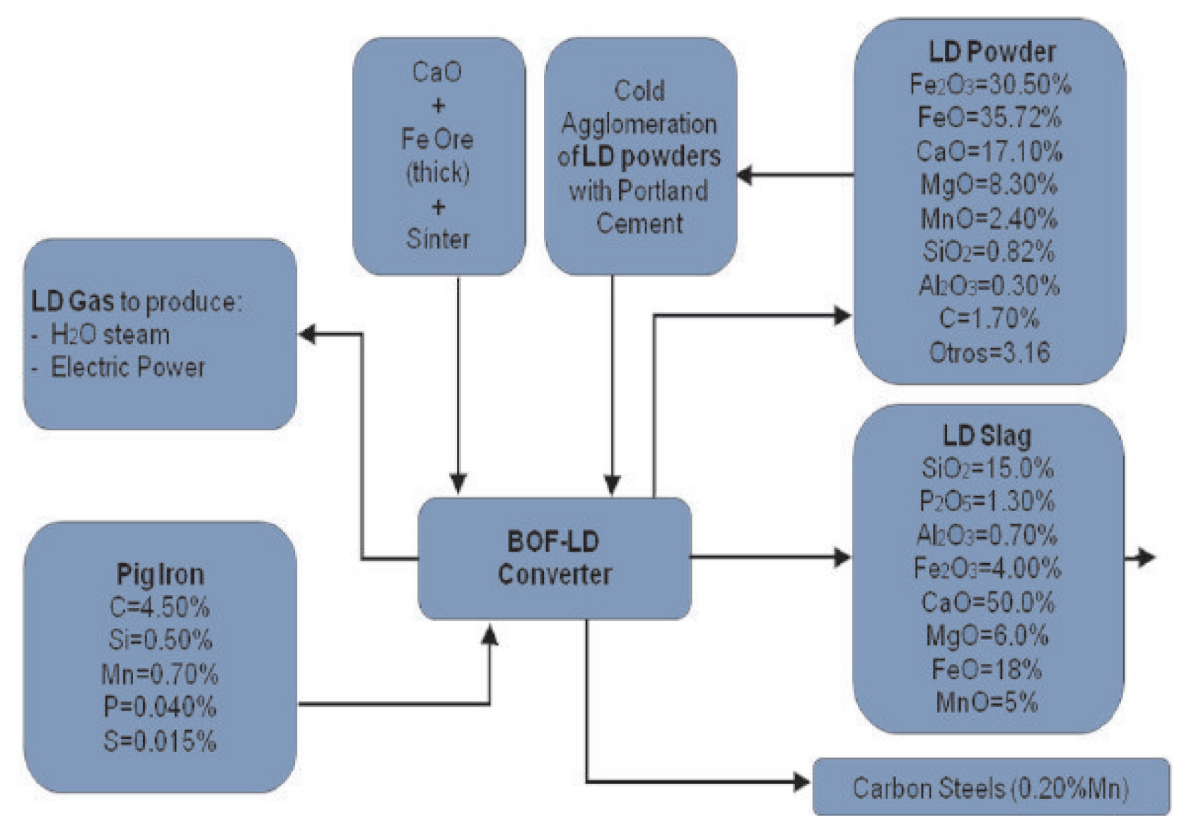

Fig. 1. Block diagram for the LD process (conventional slag)

Within the scope of this paper, it is of interest to note the nature and characteristics of the slag and dust produced by the metallurgical activity of pig iron refining. There are two options when it comes to handling LD dust:

a) Recycling it to sintering

b) Cold agglomerating with Portland cement [4]. 
Kinetically, reactions in the BOF-LD are very fast: the processing time is between 16 and 20 minutes, depending on the quality of carbon steel sought. The first 4-5 minutes of oxygen blowing are, kinetically speaking, not very productive: the decrease in the percentage of carbon is around $0.50 \%$ (500 thousandths of carbon). This phenomenon is usually attributed to the fact that the slag responsible for the kinetics of refining in BOF-LD is not yet formed. That is, from the kinetic point of view, it is accepted that there is an induction period of 4-5 minutes [5].

Typically, the products used for the LD slag are steel quality lime $(\mathrm{CaO})$ and iron ore (coarse grain size, 20-50 mm) or sinter. During the induction period (4-5 minutes), in addition to the reactions of iron refining by the oxygen gas dissolved in the molten metal, the corresponding reactions which will result in the formation of molten slag are taking place: the heating of oxides and the beginning of the corresponding eutectic reactions.

In the case of BOF-LD processing, slag can be simulated by a compound formed by pseudo-ternary $\mathrm{CaO}-\mathrm{FeO}-\mathrm{SiO}_{2}$. The information provided by this triad indicates that the temperature of $1,125{ }^{\circ} \mathrm{C}$ produced the following eutectic reaction among solid solutions (ss) of $\mathrm{CaO}, \mathrm{FeO}$ and dicalcium silicate:

$$
\mathrm{CaO}(\mathrm{ss})+\mathrm{FeO}(\mathrm{ss})+\mathrm{Ca}_{2} \mathrm{SiO}_{4}(\mathrm{~s}) \Leftrightarrow \operatorname{Liquid}\left(28 \% \mathrm{CaO} ; 71 \% \mathrm{FeO} \text { and } 1 \% \mathrm{SiO}_{2}\right)
$$

One thing that we want to do in this paper is to introduce the concept of ,preformed synthetic slag". If a product containing all the compounds of the aforementioned ternary eutectic reaction with features similar to those of a sinter or pellet could be obtained outside the converter, it would be the ideal ,preformed synthetic slag” for the BOF-LD. If in addition, as a result of homogenization-agglomeration processes, the "preformed synthetic slag" could be introduced into the converter preheated, it would substantially reduce the induction period in the process of BOF-LD refining.

As shown in Figure 1, those chemicals involved in the ternary eutectic reaction of BOL-LD steel production are usually introduced separately and not as a single compound. The induction time, therefore, is equivalent to the sum of the following contributions:

a) The amount of time needed to heat the materials from ambient temperature.

b) The amount of time required for the reduction of iron oxides.

c) The time necessary to form the corresponding solid solutions (ss, $\mathrm{CaO}-\mathrm{FeO}$ ).

d) The time it takes to synthesize dicalcium silicate, $\mathrm{Ca}_{2} \mathrm{SiO}_{4}$.

e) Or, the time needed for the terniary eutectic reaction itself.

\section{NEW FORMATION OF LD SLAG}

As shown in Figure 2, the proposed changes affect only the physical-chemical characteristics and subsequent handling of by-products (LD slag and converter dust), not the operational guidelines currently in force in BOF-LD plants. Finally, it is important to note that in meeting the new specifications for the proposed LD slag, as can be seen in Figure 2, the manganese on annealing reaches levels of $1.0 \%$. 


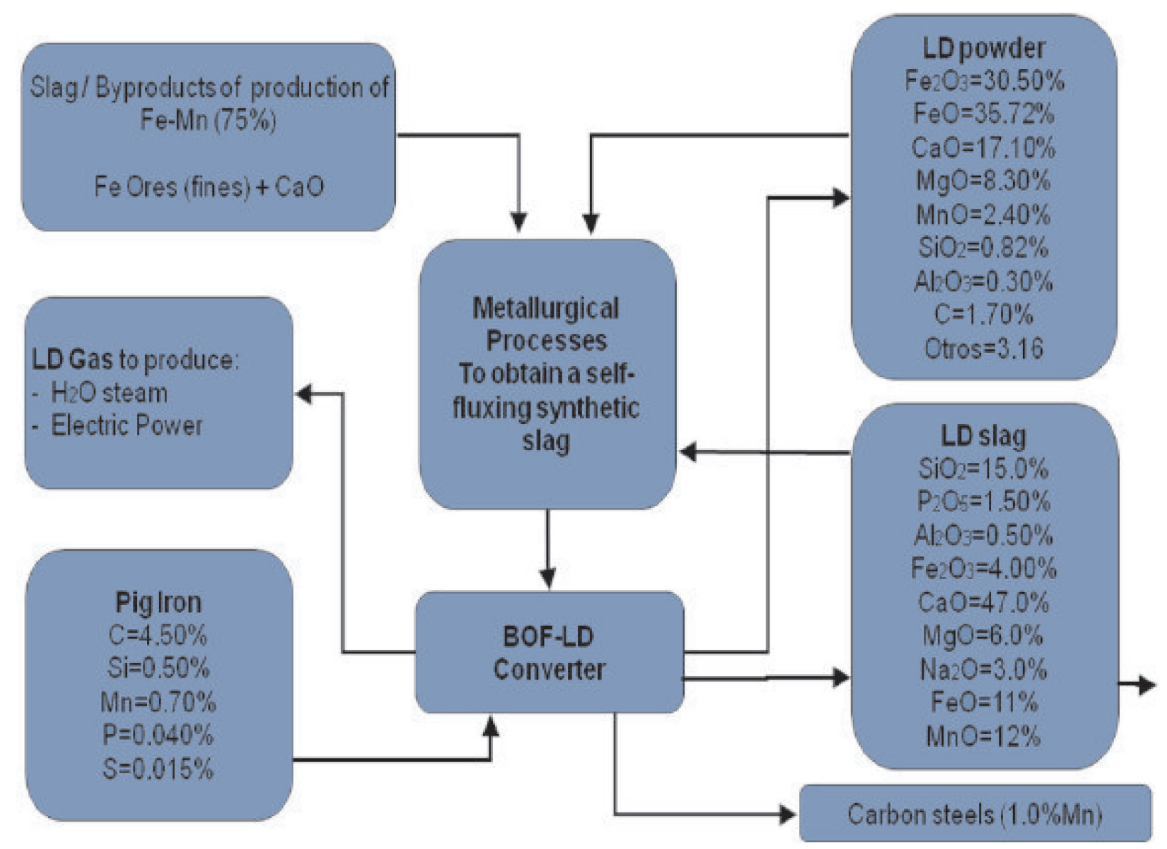

Fig. 2. Block diagram for the LD process (with a new proposal for the slag produced)

Based on data provided by Jung et al. [6], the coefficient of distribution, or distribution of manganese between the slag $(\% \mathrm{MnO})_{\text {slag }}$, and the metal $(\% \mathrm{Mn})_{\mathrm{Fe}-\mathrm{C}}$, equals:

$$
\log \frac{(\% M n O)_{\text {slag }}}{(\% M n)_{F e-C}}=\frac{14.270}{T(K)}-6.55
$$

For a temperature of $1873 \mathrm{~K}\left(1600^{\circ} \mathrm{C}\right)$

$$
\frac{(\% M n O)_{\text {slag }}}{(\% M n)_{F e-C}}=11.72
$$

where $(\% \mathrm{MnO})_{\text {slag }}=12$, referring to Figure 2 , the value of $(\% \mathrm{Mn})_{\mathrm{Fe}-\mathrm{C}}=1.02 \%$.

Of further interest is the fact that the presence of significant amounts of $\mathrm{Na}_{2} \mathrm{O}$ in the slag improves both the thermodynamics and kinetics of slagging phosphorus and sulfur from cast iron.

The slag proposed, Figure 2, could either be used in applications currently scheduled for LD slag, or it could be recycled in cases when the supply of waste materials from manganese extraction is not steady $[7,8]$. 
Moreover, the alternatives to the use of manganese and iron metal from the slag can be varied by combining hydrometallurgical treatment with operations of a pyrometallurgical character. What needs to be clear is that the product from the converter will have a high $\mathrm{MnO}$ content as well as a high content of the compounds needed for low temperature eutectic reactions, which will result in a substantial decrease in slag formation time (it is thought that BOF-LD induction times could be reduced by up to $50 \%$ ), which is at the heart of the concept of ,preformed synthetic slag”.

\section{CONCLUSIONS}

This paper is to propose a new BOF-LD slag process and a joint treatment of converter dust and raw materials that make up slag, so that the following objectives can be achieved:

a) Ensure that the level of manganese in molten metal obtained in the BOF-LD is at least $1.0 \% \mathrm{Mn}$.

b) Reduce „the induction period" characteristic of the BOF-LD thermal refining process by two minutes through the concept of preheated ,preformed synthetic slag".

\section{Acknowledgements}

The authors wish to thank the Ministry of Education and Science (MEC): MAT200300502, the Ministry of International Affairs and Cooperation (MAEC): MAEC-AECI-B/ 1629/04; B/2884/05; B/5814/06, B/7648/07, Regional I+D+I in Asturias (Science, Technology and Innovation Plan, FICYT) for the financial support and the CSIC-Madrid (Spain) for making the scientific and technological cooperation between CENIM/CSIC, Oviedo University and University of Science and Technology Krakow possible through the "Associated Unit".

\section{REFERENCES}

[1] Cengizler H., Eric R.H.: Activity of $\mathrm{MnO}$ in $\mathrm{MnO}-\mathrm{CaO}-\mathrm{MgO}-\mathrm{SiO}_{2}-\mathrm{Al}_{2} \mathrm{O}_{3}$ slags at $1500{ }^{\circ} \mathrm{C}$, Steel Research Int., 77 (2006) 11, 793-802

[2] Sancho J.P., Fernández B., Ayala J., García P., Recio J.C., Rodríguez C., Bernardo J.L.: Method of obtaining electrolytic manganese from ferroalloy production waste, $1^{\text {a }}$ Conferencia Nacional sobre avances en el reciclado en materiales y eco-energía (www.recimat.wordpress.com). Madrid, 12-13 Noviembre (2009)

[3] Deo B., Boom R.: Fundamentals of Steelmaking Metallurgy, Ed. Prentice Hall International, New Cork, USA (1993) 21-29

[4] Duda W.E.: Manual Tecnológico del Cemento. Ed. Editores Técnicos Asociados S.A., Barcelona, (1977) 4-7

[5] Sancho J.P., Verdeja L.F., Ballester A.: Metalurgia Extractiva: Procesos de Obtención, Ed. Síntesis, Madrid (2000) 86-91 
[6] Jung S.M., Rhee Ch.H., Min D.J.: Thermodynamic properties of manganese oxides in BOF slags. ISIJ Int., 42 (2002) 1, 63-70

[7] Saiz Zapico M.N.: Aprovechamiento de polvos del tragante de un horno de ferromanganeso, Proyecto Fin de Carrera ETSIM de Oviedo. Director: J.P. Sancho. 13 de Octubre de 1999

[8] De Frutos Santamaría J.L.: Modelización matemática de un horno eléctrico trifásico para producción de Fe-Mn HC, Proyecto Fin de Carrera ETSIM de Oviedo. Director: J.P. Sancho. 15 de Abril de 2003

Received

November 2011 